\title{
a companhia brasileira de paquetes a vapor e a centralidade do poder monárquico
}

\author{
Almir Chaiban El-Kareh \\ Prof. Doutor do Departamento de História da UERJ
}

\section{RESUMO}

O Estado brasileiro recém-criado teve que ser construído. As grandes distâncias do País favoreciam o surto de sentimentos regionalistas. A centralidade do poder só era possível com o desenvolvimento das comunicações. A Companhia Brasileira de Paquetes a Vapor, ligando todas as capitais marítimas, foi responsável pela distribuição da correspondência postal e transformouse numa peça fundamental da implementação das decisões políticas da Monarquia, garantindo sua territorialidade e sua efetiva capacidade de penetrar a sociedade civil. Mas, ao se deixar cooptar pelo Estado, em troca de privilégios e subvenções, ela se acomodou e não se modernizou. Ao perder o direito ao monopólio, não suportou a concorrência estrangeira e acabou sucumbindo.

Palavras-Chave: companhia brasileira, navegação a vapor, comunicações, centralidade, poder monárquico.

\begin{abstract}
The Brazilian state after the country's independence had to be built up. Its great internal distances favoured the rise of regionalist feelings. The national state's power centrality would only become possible through the development of Communications with the regions. The Companhia Brasileira de Paquetes a Vapor (Brazilian Steam Navigation Company), by linking the capitais of all maritime provinces, had taken responsibility for the distribution of mail, and thus transformed itself in one of the fundamental means for implementing the political decisions of the monarchy, by warranting its territoriality and effective capacity to penetrate the civil society. But, through its privileges and subventions, this company was assimilated by the state, failing to modernize itself. At the end of its monopolistic concession, it was unable to face foreign competition and went bankrupt.
\end{abstract}

Key words: Brazilian company, steam navigation, Communications, centrality, monarchical power.

Politicamente esgotado pelas revoltas que eclodiam de norte a sul desde a abdicação de D. Pedro I, e que ameaçavam a sua unidade, o País encontrou na antecipação da maioridade do príncipe D. Pedro de Orléans e Bragança, com apenas catorze anos de idade, a saída para o caos que reinara durante toda a Regência. 
Mas, se a presença do herdeiro da Coroa no trono dava mais legitimidade ao poder monárquico (substituindo as figuras regenciais que haviam sido incapazes de se impor a toda a nação como símbolos de sua unidade, e aos representantes legítimos dos díspares interesses regionais) e apaziguava, ainda que parcialmente, os ânimos das forças sociais que atuavam no sentido da maior autonomia em relação à Corte, esta presença não era suficiente para inibir os movimentos centrífugos.

Os políticos favoráveis a fortalecimento do poder monárquico centralizado perceberam que era preciso dar continuidade às reformas do Estado, empreendidas no período regencial, aprofundando-as. E mais do que isso, que era preciso dar a este poder central, não apenas um monarca que encarnasse a união de toda a nação através da combinação de seus distintos interesses, mas a sua síntese, almejada no poder moderador, único (por sua posição suprapartidária e por sua centralidade, portanto por situar-se acima dos interesses regionais) capaz de interpretar os verdadeiros anseios da nação. E, para alcançar este objetivo, era necessário dar-lhe uma base de sustentação política,jurídica e ideológica não apenas sólida como real. Em outras palavras, era necessário que estas reformas saíssem do papel e se tornassem efetivas. E, para que isto ocorresse, era necessário que as decisões tomadas na Corte alcançassem, o mais rapidamente, todo o País.

A concretização deste ideal centralizador implicava na mobilização daqueles setores sociais mais interessados na manutenção da paz e na unidade territorial do Brasil. Entre eles estavam os políticos, movidos por razões puramente ideológicas ou não; os comerciantes, desejosos de tirar vantagens da constituição de um mercado nacional só possível se interligado por vias e transportes rápidos e eficientes, como as estradas-de-ferro e as embarcações a vapor, e a quem o telégrafo elétrico viria dar um dinamismo inusitado ao permitir que as notícias pudessem chegar ao mesmo tempo em todos os pontos do Império, e no qual as trocas se fizessem através de uma moeda única.

Estavam, também, os produtores exportadores ou não, animados não só por estas facilidades econômicas, além de portos e armazéns modernos, que barateassem o preço de seus produtos nos mercados internacional e interno, mas também pela garantia da ordem pública, tão necessária a o bom desempenho da economia, além da possibilidade de defender e impor, de modo mais eficaz, seus interesses de classe junto aos poderes públicos, regionais e central.

Assim como também estavam os editores e gráficos, especialmente os responsáveis pela edição, distribuição e venda dos jornais, que só 
poderiam ganhar com a unidade do mercado e a rapidez de suas comunicações; e todos aqueles brasileiros que viviam longe da Corte e sempre ávidos de notícias a respeito do se passava ali e no mundo, e que só poderiam satisfazer sua curiosidade através da chegada dos jornais. Isto, além, é claro, da população em geral que, como se não bastassem as doenças e epidemias, ainda se via maltratada pelas guerras fratricidas, e que só poderia beneficiar-se do fim destas, e do alívio que seria possível dar àquelas por uma assistência pública mais rápida e eficiente.'

Só o aparelho de Estado, apesar de todas as adversidades que encontrava pela frente, possuía os meios para mobilizar ideológica e materialmente setores tão díspares da sociedade e, ao mesmo tempo, servir de espaço para a realização de alianças capazes de sacrificar os interesses de classe mais imediatos, agora vistos como de menor importância, em nome de interesses comuns, confundidos com os interesses de toda a nação, tidos como superiores, ainda que apenas realizáveis a mais longo prazo.

O Estado imperial, pouco a pouco, foi trazendo para o seu campo, ou seja, para o terreno do político e dojurídico, as lutas que, até então, se travavam nos campos de batalha, nas ruas e nos jornais. Mas, não com o fim de fazê-las desaparecer, pois eram elas que justificavam sua própria existência enquanto Estado, enquanto poder mediador; e, sim, no intuito de domesticá-las, subordiná-las aos interesses centralizadores deste mesmo Estado, encarnados no poder Moderador do monarca, que se fortalecia enquanto representação de todos os interesses sociais politicamente organizados.

Mas, era também preciso dar uma nação ao Estado recém constituído. E para isto, não bastava formar uma elite política com uma mentalidade e um projeto social nacionais. ${ }^{2}$ Era preciso fazer com que as populações de todas as partes do País, já unidas por uma mesma língua e religião, se sentissem concernidas por ideais comuns; que as desconfianças interprovinciais, especialmente das províncias do Norte em relação às do Sul, desaparecessem e dessem lugar à cooperação e à solidariedade, e a Corte do Rio de Janeiro fosse vista como o símbolo desta unidade. E mais, era preciso fazer sentir a presença, se não física,

Almir Chaiban El-Kareh, "Fièvres et Santé Publique: l'Annus Horribilis à Rio de Janeiro" in Histoire, Economie et Société, 20(3), 3e Trimestre 2001, p. 310.

José Murilo de Carvalho, A Construção da Ordem - a Elite Política Imperial, Rio de Janeiro: Ed. UFRJ/Relume Dumará, 1996. 
ao menos simbólica, do monarca em todas as partes do Império. Faziase mister, portanto, que o poder monárquico se materializasse em ações sociais concretas.

Dentro desta perspectiva, da construção da unidade nacional, a questão da unidade territorial, juntamente com a da unidade administrativa, ocupava um lugar especial nas preocupações do Governo. E, forçosamente, sua solução tinha a ver com o desenvolvimento comercial. Logo, com uma participação bastante estreita da burguesia na política centralizadora do poder monárquico, sobretudo a partir da introdução das máquinas a vapor nos meios de transporte, que, pela sua rapidez, multiplicavam os contatos comerciais, e os preços tendiam a baixar, a se igualar e a se nivelar, diminuindo as disparidades entre os mercados regionais e, em conseqüência, diminuindo também as queixas contra a praça da Corte, vista como prepotente e opressiva.

"É, senhores, esta a principal necessidade do Império, e de que depende o seu futuro, porquanto nós estávamos separados uns dos outros como o estamos da China, e assim necessariamente existirão todos estes inconvenientes, todos estes males que notamos nas nossas localidades; e mesmo essas paixões desenfreadas, esses ódios que não se aplacam quase nunca. É sempre o comércio que após de si traz a civilização, e é sempre a civilização que adoça os costumes, e inteiramente acaba com todos esses males provenientes do espírito de partido, do espírito de rivalidade, do ódio e paixões das localidades." ${ }^{3}$

O papel das companhias de navegação a vapor, neste processo de unificação política, foi primordial. Destas, a mais importante foi, sem dúvida, a Companhia Brasileira de Paquetes a Vapor.

A introdução da máquina a vapor vinha revolucionar toda a sociedade.Transportes mais rápidos e eficientes de mercadorias e passageiros diminuíam os tempos de percurso e as distâncias, e afetavam não só a vida econômica e social, estimulando o comércio, o turismo e as migrações; mas, também, os valores e costumes dos povos e suas ideologias, além de possibilitar ações políticas e militares de maior alcance, mais rápidas e mais eficazes. Logo, ela não só beneficiava a burguesia, mas as classes dominantes em geral e seus Estados.

Brasil, Anais do Senado do Império (doravante Senado), Ângelo da Silva Ferraz, Sessão de $12 / 07 / 1856$, p. 351 . 
No que dizia respeito ao Estado monárquico brasileiro, especialmente a partir da abdicação de D. Pedro I, a subordinação das províncias a poder central, regencial, tornara-se uma obsessão, tanto mais quanto sua legitimidade era contestada. Daí as palavras de Paula Souza, pronunciadas em sua defesa na sessão do Senado de 11 de agosto de 1836:

"(...) por achar-se o Regente à testa dos negócios do Estado, não deixa de existir o Governo Monárquico Representativo, e mal da Nação se todos tivessem [este] pensamento (...), pois o que faz com que existam os elementos de ordem, união e estabilidade, é o pensamento de que o Chefe do Estado é o Monarca, conquanto ele não tenha o devido movimento, por causa de sua idade; mal da Nação se acaso o povo vier a pensar que, tendo vivido 11 ou 12 anos debaixo do Governo Eletivo,julgue desnecessário o Governo Monárquico."

Nesta mesma sessão, durante a discussão do projeto que ampliava as atribuições do Regente concernentes à dissolução da Câmara dos De putados, o Marquês de Barbacena era ainda mais taxativo:

"(...) enquanto não houver facilidade de comunicações, e não se poder reunir a Câmara em três ou quatro meses, a dissolução será fatal a quem a fizer, ou seja o Regente ou o Imperante. Admitindo mesmo que bastem nove meses para se reunir a nova Câmara, o que é muito duvidoso, nem assim evitaremos o risco de findar o ano financeiro sem nova lei de orçamento. Ficar o Governo sem meios de pagar aos empregados públicos, é horrível; mas cobrar o Governo sem autorização da Assembléia Legislativa, ainda é mais horrível. Quando houver facilidade de comunicações por mar e por terra, haja autoridade de dissolver a Câmara Eletiva, mas no estado atual não convém." s

A extensão continental do território brasileiro e os obstáculos interpostos pela Serra do Mar ao avanço rumo ao interior, aliados à relativamente pequena quantidade de rios navegáveis, deixavam o governo central sem escolha: se quisesse fazer valer sua autoridade seria obrigado a reduzir as distâncias.

Paula Souza, Senado, Sessão de 11/08/1836, pp. 269-270.

Marquês de Barbacena, Senado, Sessão de 11/08/1836, p. 269. 
No que dizia respeito às províncias marítimas, as mais numerosas, a

EXTENSÃOda costa brasileira era compensada, especialmente no litoral norte, pelo fato dela ser salpicada de portos naturais, o que facilitava a c o m u n i c a çã o porvia aquática. ${ }^{6}$ Isto explica porque, do ponto de vista do exercício do poder, a navegação a vapor ocupava, nas preocupações do Governo, um espaço privilegiado.

Foi, portanto, nestas condições, como parte da política de centralização do poder que, o Decreto de 22 de abril de 1836, justificava a criação de uma companhia de navios a vapor da seguinte maneira:

"(...) como as necessidades da administração pública e os interesses comerciais muito reclamam, e considerando que o indicado fim só pode ser conseguido por meio de paquetes a vapor: há por bem de aprovar o contrato (...) com o negociante estabelecido nesta praça [do Rio de Janeiro] João Tarrand Thomaz."

E, a 9 de maio de 1837 , eram aprovados, em assembléia geral dos acionistas, os estatutos fundadores da Companhia Brasileira de Paquetes a Vapor, com o direito de explorar, por dez anos renováveis, a ligação marítima entre a Corte e as cidades do Norte até o Pará. Tratava-se da primeira empresa brasileira de navegação a vapor de longo curso.

Se acompanharmos o processo de expansão desta linha de navegação, teremos a surpresa de descobrir o paralelismo entre a inclusão de novos portos em seu trajeto e as sublevações das províncias que eram por ela servidas. Desta forma, alarmado com as revoltas que ameaçavam sua unidade territorial e política, o Governo Central, diante da necessidade urgente de levar reforços em homens e armas às províncias sublevadas, encontrava na navegação a vapor, especialmente nesta companhia, a sua maior aliada na solução de seus problemas de ordem militar.

Por outro lado, mesmo depois de haverem sido introduzidas as estradas-de-ferro, a navegação a vapor continuou sendo o transporte mais barato: os caminhos eram naturais; a água oferecia menos resistência à tração, possibilitando que um cavalo vapor, na velocidade de um metro por segundo, deslocasse de 60 a 100 toneladas, enquanto que, em caminho ferro, em declive, apenas 15 toneladas; e os veículos aquáticos, especialmente os marítimos, de grande calado, eram de quatro a dez vezes maiores que os de terra, e o custo de sua construção cinco vezes menor. Afonso Costa, A Marinha Mercante no Brasil: estudos, projetos c reforma. Rio de Janeiro: Liga Marítima Brasileira,1910, p. 73.

Cia. Brasileira de Paquetes a vapor, Estatutos (doravante, Estatutos da Cia. Brasileira), Rio de Janeiro: J. Villeneuve, 1837. 
No entanto, era do ponto de vista do funcionamento do próprio poder, de sua administração, que ela representava um papel essencial pois eram seus navios que transportavam todos os malotes com as correspondências públicas e privadas, como decretos e decisões governamentais, e o dinheiro para que as tesourarias provinciais pudessem pagar os funcionários do Governo, sem o que o aparelho de Estado emperraria. Deste ponto de vista, a chegada periódica dos paquetes da - Companhia Brasileira às capitais provinciais reforçava os laços entre as províncias, e delas com a Corte, e reavivava a presença do poder central. E as viagens da Família Real em seus vapores, fazendo-se de corpo presente em suas visitas às Províncias, não fizeram senão acentuar esta relação simbólica com o Estado imperial, liberal e paternal.

"Por certo, se as diferentes parte do Império estivessem reduzidas às suas mesquinhas forças, dada qualquer necessidade superior aos seus recursos não teriam meios de satisfazê-la; ao contrário, no nosso sistema, os recursos correm de pronto do centro aos extremos, do centro aos outros pontos intermédios desse grande território.Com mão liberal, ou antes com mão paternal, o governo imperial tem obrigação de levar a todos os pontos, a todas as populações o conforto, o remédio, os recursos precisos para satisfazer suas necessidades. O estado de solidão ou de isolamento é sempre fatal, da união resulta força e poder, e a paz desta base e prosperidade."

E como o funcionamento pleno do Parlamento brasileiro, no Rio de Janeiro, dependia do comparecimento dos parlamentares às suas sessões, que deviam se iniciar sempre no dia 3 de maio de cada ano, para que pudessem encerrar-se em fins de setembro, de forma a assegurar, ao menos, cerca de sete meses de recesso (o que, devido às distâncias e ao tempo das viagens, não era excessivo) para que os legisladores, especialmente os do Norte, pudessem retornar às suas províncias e reavivar seus vínculos com as bases eleitorais, e estar de volta, pontualmente, para o início da legislatura seguinte. A este respeito, o senador Hollanda Cavalcanti, na sessão de 22 de setembro de 1848 , da $7^{\star}$ legislatura, que só viria a terminar, tardiamente, no dia 05 de outubro, referindo-se aos colegas quejá se retiravam para suas províncias, esvaziando o plenário, comentava, dirigindo-se ao presidente do Senado:

"Ângelo da Silva Ferraz, Senado, Sessão de 12/07/1856, pp. 353-354. 
"Não sei seV. Exa. leu o Jornal de hoje; na barca que saiu ontem, para o norte, lá foram dez; hoje saiu outra para o sul,-não sei quantos iriam; o negócio parece que se está desfazendo."

Seus estatutos, aprovados pelo decreto de 22 de abril de 1836 , estabeleciam como obrigação primordial da Cia. Brasileira de Paquetes "cumprir exatamente o contrato celebrado" com o Governo Regencial, ou seja, "conduzir com regularidade, em dias e horas determinadas, as malas e ofícios do governo", desde a Corte até Belém do Pará, com paradas na Bahia, Alagoas, Pernambuco, Ceará e Maranhão. Em troca, receberia o pagamento de 8 contos de réis mensais. "Secundariamente, segundo os mesmos estatutos, vinham suas atividades propriamente comerciais, podendo transportar cargas e passageiros, sempre que isto não estorvasse seu principal objetivo, que era o de servir ao Estado.'

Em se tratando de uma companhia de navegação privada, esta inversão dos objetivos de suas atividades, pela qual seus fins econômicos se subordinavam à sua função política, explicava-se, no momento de sua criação, pelo fraco desempenho do comércio interprovincial, que era compensado por um substancial pagamento pelos seus serviços prestados ao Governo, e acentuava sua função no processo de consolidação e unificação do Estado imperial. Seu papel, como instrumento de ação política, administrativa e militar, era de tal importância, que oVisconde de Abrantes considerava a sua subvenção como um dos "primeiros deveres do Estado", pois, segundo suas palavras no Senado, na sessão de 22 de setembro de 1848:

"[A navegação a vapor] se liga aos três interesses nacionais, o interesse político, o administrativo e o comercial. Falar hoje em navegação de vapor e falar de interesse público é uma mesma coisa."12

A contrapartida oferecida pelo Governo Brasileiro aos seus serviços, além daqueles 8 contos de réis e do privilégio da ligação da Corte com o Norte, era a sua prioridade na ligação com o Sul, quando ela viesse a

Hollanda Cavalcanti, Senado, Sessão de 22/09/1848, p, 302.

Estatutos da Cia. Brasileira, Capítulo I,Artigos $2^{\circ}, 6^{\circ}$ e $7^{\circ}$.

Idem.Art. $7^{\circ}$.

Visconde de Abrantes, Senado, Sessão de 22/09/1848, p, 299. 
ser necessária ao Governo Imperial, ${ }^{13}$ e a sua preferência no caso em que ele viesse a ter que transportar passageiros ou cargas, não estipulados no contrato, como o "carregamento de munições de guerra e artigos bélicos, pagando por tudo um frete razoável"."

Contudo, desde a inauguração da linha dos correios transatlântica da Companhia Real Britânica, ${ }^{15}$ em 1850, que ligava o Rio de Janeiro não só a Southampton, na Inglaterra, passando pela Bahia e Pernambuco, como também a Montevidéu e Buenos Aires, o serviço da Companhia Brasileira passou a ser fortemente criticado pela morosidade e falta de conforto de seus vapores. Desde então, a política governamental de estimular o "progresso material" — fosse através "dos empréstimos ou avanço de dinheiro aos particulares para empreenderem suas obras" como ao Estaleiro de Mauá, ou através do estabelecimento de "um capital fixo para garantir osjuros de acionistas, particulares comprometidos em uma empresa", ${ }^{16}$ como no caso da Companhia Brasileira passou a ser veementemente atacada pelos liberais, como Hollanda Cavalcanti que alegava que:

"(...) os melhoramentos destes correios são principalmente para o transporte das cartas, porque estou persuadido que esse direito que tem o governo de dois passageiros em uma viagem não é lá tão transcendente; a maior vantagem é facilitar a comunicação na transmissão de correspondências." E acrescentava: "Antes deste melhoramento [quando as cartas vinham em barcos a vela], quando chegava um navio do norte, eu recebia, duas horas depois, as minhas cartas, e pagava dois vinténs por cada carta; depois com o melhoramento do vapor eu recebo a carta 24 horas pelo menos depois da chegada do vapor, e pago seis vinténs. Não me queixo (...) contanto que haja a vantagem da presteza e exatidão nas comunicações. (...) Mas esta mesma razão da presteza e pontualidade das correspondências faz com que hoje eu não queira remeter cartas pelos correios brasileiros a vapor, que antes queira pagar doze vinténs pela carta que remeto

Estatutos da Cia. Brasileira, Capítulo I, Art. 13º.

Idem,Art. T.

"Cf.Almir Chaiban El-Kareh,"0 Rio de Janeiro e as primeiras linhas transatlânticas de paquetes a vapor: 1850-1860", in CD Rom/IV Congresso Brasileiro de História Econômica e $5^{\circ}$ Conferência Internacional de História de Empresas, São Paulo, 2 a 5 de setembro de 2001 , FEA-USP.

${ }^{16}$ Hollanda Cavalcanti, Senado, Sessão de 27/05/1852, p. 225. 
pelos paquetes ingleses; são mais prontos, mais pontuais e esta celeridade e pontualidade sem dúvida é preferível ria comunicação." ${ }^{\prime}$

Entretanto, o ministro do Império, Gonçalves Martins, em agosto de 1852, diante do Senado, vinha em defesa da Companhia e assim justificava o aumento da subvenção:

"E não é possível que se deixe de dar a esses vapores uma subvenção maior do que dá de ordinário a Inglaterra aos que fazem as suas comunicações; os vapores ingleses São de comércio, transportam mercadorias e grande número de passageiros, a subvenção é apenas auxiliar; os da Companhia pouco ou nada têm a esperar das mercadorias, e os passageiros, pelo movimento natural da população, são poucos." 18

Posteriormente, no contrato de 1859, quando sua linha do Nortejá realizava 24 viagens redondas em 540 dias, ${ }^{19}$ ou seja, num ano e meio, e a sua linha do Sul já alcançava Montevidéu, no Uruguai, em troca do "transporte gratuito de somas de dinheiro remetidas pelas estações de fazenda de uma para outras Províncias ou portos de escala, e desta Corte para diferentes pontos e vice-versa", e da obrigação de "transportar gratuitamente, em cada viagem simples, quaisquer volumes, cujo peso total não exceder 20 arrobas ou de 60 palmos cúbicos", a Companhia teve sua subvenção elevada; ${ }^{20}$ o que eqüivalia ao reconhecimento, por parte do Governo, da importância e vantagens do seu serviço.

A médio prazo, este atrelamento ao Estado, que lhe garantia lucros fáceis, terminou por se traduzir num certo desinteresse, por parte de sua direção, em investir na modernização de suas oficinas e de seus navios, alguns de segunda mão, adquiridos de companhias inglesas, ser-

Idem, p. 226.

18 Gonçalves Martins (Ministro do Império), Senado, Sessão de 123/08/1852, p. 366.

${ }^{19}$ Os vapores da linha do Norte percorriam por ano 109.152 milhas e recebiam o subsídio anual de 768:000\$000, ligando o Rio de Janeiro ao Pará, passando pela Bahia, Alagoas, Pernambuco, Paraíba,Rio Grande do Norte, Ceará e Maranhão. Os da linha do Sul ligavam o Rio de Janeiro a Montevidéu, percorrendo $58.320 \mathrm{mi}$ lhas, e recebiam a subvenção de 288:000\$000. A. C.Tavares Bastos, O Vale do Amazonas, 3 $3^{\text {a }}$ ed.,São Paulo: Editora Nacional, 1975, pp. 111-112.

${ }^{20}$ Cia. Brasileira de Paquetes a Vapor, Relatório (doravante, Relatório da Cia. Brasileira) de 31/03/1860, Rio de Janeiro: M. Barreto, 1860. 
vindo de motivo, já em 1852, à crítica do senador D.Manoel Mascarenhas de que:

"(...) os vapores são velhos, ronceiros, que o serviço é portanto mal feito, e que mesmo o tratamento dos passageiros não é o me lhor, comparado principalmente com o que se dá a bordo dos paquetes ingleses, onde as passagens são mais baratas para Bahia e Pernambuco." 21

Nesse mesmo ano, o senador Hollanda Cavalcanti considerava a consignação anual de 720 contos de réis "para alimentar a companhia dos correios de vapor", um fator de desestímulo à iniciativa privada e de desperdício do dinheiro público. Para ele, no começo, a idéia de contratar o serviço de transporte da correspondência do Governo havia sido boa e havia dado certo. Mas, já era hora do governo cuidar de seus próprios interesses, porque:

"A direção da companhia tendo a certeza do auxílio que se lhe presta, para que há de melhorar a empresa? O que lhe convém é manter as coisas como estão. Assegure a direção $12 \%$ [de dividendos] aos acionistas, corram as coisas como quiserem (...). Senhores, tal maneira de proteger é prejudicial ao progresso da indústria; melhor é aproveitarmo-nos desses vapores estrangeiros: então temos uma boa economia a fazer. Podemos mesmo ganhar mais sem exigir um porte tão elevado. Se todavia se achar conveniente conservar uma companhia de vapores para prestar-se a outras necessidades públicas, então vamos estendendo nossos meios de comunicação: procuremos o Amazonas, multipliquemos as comunicações entre o Pará e Pernambuco, porque entre Pernambuco e Rio de Janeiro satisfazem essas carreiras da companhia estrangeira, mas entre o Pará e Pernambuco não há senão um vaporzinho, e quando aparece!" 22

Portanto, desde o início dos anos 1850 , a concorrência dos vapores estrangeiros, especialmente os da Companhia Real Inglesa, de Southampton, começava a diminuir a importância da Companhia Brasileira no que dizia respeito à distribuição da correspondência privada e do

D. Manoel, Senado, Sessão de 11/08/1852, p. 358 .

${ }^{22}$ Hollanda Cavalcanti, Senado, Sessão de 27/05/1852, pp. 225-226. 
transporte de passageiros, ainda que apenas naqueles portos nacionais, de escala obrigatória, que tocava, pois lhes era vedada a navegação de cabotagem, privilégio dos nacionais. No entanto, havia aqueles, como o Ministro do Império, que ainda acreditavam que não seria de bom alvitre entregar o serviço dos correios a companhias estrangeiras, ainda que com isso se pudesse obter uma grande economia, porque poderia colocar em risco a confiança das Províncias no Governo Central e, em conseqüência, a sua política de centralização do poder, que tanto dependia de sua comunicação com elas:

"Talvez que isso fosse uma economia, porque além dos vapores ingleses da companhia existentes, têm de vir outros: mas o que não sei é se conviria ao governo não ter seus correios próprios no País, independentes da condução do estrangeiro, para a nossa correspondência oficial; não sei se seria isso acertado. Se o governo quisesse fazer esta economia, talvez despertasse o ciúme patriótico, e fosse argüido de confiar a administração de nossas províncias, talvez a sorte delas, às mãos e dependência do estrangeiro." ${ }^{23}$

A necessidade de manter comunicações rápidas e freqüentes entre a Corte e as Províncias a fim de estreitar os laços entre elas, ou, em outras palavras, a fim de subordinar as Províncias à administração central, transparecem em suas palavras:

"Eu direi que não só fez algum bem o estabelecimento dessa companhia de vapores; mas um bem imenso. Porém creio mesmo que já ouvi dizer ao nobre senador [Hollanda Cavalcanti] que esta freqüência de correspondência tinha sido um mal para as províncias do Norte, talvez querendo dizer que com mais rapidez se recebiam as influências da Corte." 24

3 Gonçalves Martins (Ministro do Império), Senado, Sessão de 27/05/1852, pp. 247 248. Nesta mesma sessão, discutiu-se o projeto de construção da Estrada de Ferro de D. Pedro II, para a qual o Governo Central deveria conceder aos seus acionistas uma garantia de juro de $5 \%$ e o governo provincial do Rio de Janeiro ainda mais $2 \%$. Os senadores liberais acusavam o governo de beneficiar os "lavradores" das Províncias do Rio de Janeiro, São Paulo e Minas, em detrimento dos das Províncias.do Norte.

${ }^{24}$ Idem, p.248. 
Apesar de todas as críticas feitas pelos políticos liberais, a Companhia Brasileira continuou se beneficiando da proteção Estado imperial, em função dos importantes serviços de ordem político-administrativa que lhe prestava. Não só sua subvenção anual aumentara, passando a 1.008:000\$000, como também lhe foram dados o poder de elevar o preço das passagens e fretes até $20 \%$, a isenção dos direitos de consumo sobre os objetos considerados indispensáveis ao aparelhamento de seus vapores e, finalmente, um empréstimo de 252:000\$000 réis sem juros e a longo prazo. Com todas estas vantagens, seu estado permaneceu próspero até 1857 .

Em 1858, a sua diretoria, diante da brusca queda nas rendas da companhia, que havia no ano anterior distribuído a seus acionistas dividendos de $12 \%$, e neste só conseguira distribuir dividendos de $6 \%$, e pressionada por seus acionistas, propõe ao Governo um aumento de sua subvenção. Iniciava-se uma nova rodada de conversações com o fim de negociar um novo contrato.

A argumentação da direção da Companhia Brasileira, a fim dejustificar o seu mau desempenho, estribava-se, basicamente, em dois pontos que tinham a ver com o consumo de combustível: os paquetes recentemente adquiridos eram mais possantes, consumindo maior quantidade de carvão; e os velhos, devido ao estado de deterioração de suas caldeiras e máquinas, eram mais lentos, consumindo mais tempo nas viagens e, conseqüentemente, mais carvão.

O novo governo, conservador, formado em 10 de agosto de 1859 , tinha à sua frente Ângelo Muniz da Silva Ferraz, que, além da presidência do Conselho, acumulava também as pastas do Império e da Fazenda. Ainda que confessasse não ser avesso à proteção governamental à iniciativa privada, pois como ele mesmo afirmava:

"[era] impossível que um país novo em que predomina o espírito do individualismo, se esqueça de seu presente e de seu futuro, e se leve pela máxima terrível do laissezfaire, laissez passer, hoje em dia substituída pelas palavras ajudai, desenvolvei $e$ organizai". ${ }^{25}$

Nem por isso se deixou levar pelos argumentos da Companhia e apresentou uma nova proposta, considerada inaceitável por sua direto-

${ }_{25}$ Ângelo Muniz da Silva Ferraz (Presidente do Conselho), Anais do Parlamento Brasileiro, Anais da Câmara dos Deputados (doravante CD), Sessão de 02/08/1860, p. 29. 
ria. ${ }^{26}$ Das negociações que se seguiram, entre ambos, ficou, finalmente, estabelecido que toda vez que os lucros líquidos da Companhia chegassem a $16 \%$ do seu capital, $4 \%$ deles iriam para um fundo de reserva, enquanto este fundo não atingisse $2 / 3$ do capital; $12 \%$ seriam distribuídos aos acionistas, $S$ todo q excesso reverteria em favor da Fazenda Pública. Além disso, era-lhe concedida a prorrogação do prazo do contrato com o Governo por mais seis anos, ${ }^{27}$ o que ficou pendente da aprovação do poder legislativo. Quanto à decisão do Ministro do Império do gabinete anterior, Sérgio Teixeira de Macedo, de nomear um fiscal "como pessoa mais habilitada para extirpar abusos que dizia haver no serviço da Companhia, sobretudo no consumo do carvão", e que tanto indignara a direção da Companhia, foi suspensa "quando foram estabelecidas outras condições que a faziam desnecessária". ${ }^{28}$

$\mathrm{Na}$ sessão de 21 de agosto de -1860 , discutindo o orçamento do seu ministério diante da Câmara dos Deputados, Ferraz defendia sua atitude em relação à Companhia Brasileira:

"Eu, pois, neste pontojulgo que atendi aos interesses do Estado. A Companhia não perdeu coisa alguma; deixei-lhe o aumento da subvenção, mas entendi que devia criar uma espécie de registro, por meio do qual pudéssemos avaliar se a subvenção dada era aquém das necessidades ou além delas; que no caso de ser além das necessidades, então deveria, ou ser diminuída ou reverter para os cofres públi$\cos$ o excedente." ${ }^{29}$

No entanto, segundo a direção da Companhia, este projeto, ao ser transformado em decreto, tivera sua redação alterada em relação à minuta discutida e aprovada verbalmente pelo ministro da Fazenda, o que a levou a apelar para o Legislativo. Este desentendimento entre a Companhia e o Governo prolongou-se até 1861, quando foi proposto um adiantamento de seis meses da subvenção, ou seja, 504:000\$000, além da inovação do contrato no sentido de diminuir a despesa e o número de viagens. Mas, apenas em 22 de agosto de 1862 estas propostas foram

${ }^{26}$ Relatório da Cia. Brasileira, 31/03/1860, Rio de Janeiro: M. Barreto, 1860.

${ }^{27}$ Ângelo Muniz da Silva Ferraz (Presidente do Conselho), CD, Sessão de 21/08/ 1860 ,p. 223.

$28 \quad$ Idem, p. 224.

29 Idem, p. 223. 
transformadas em lei, e só vieram a ter execução no ano seguinte, quando, sem autorização, o Governo prorrogou até 1872 o prazo do contrato de 17/12/1859, que deveria findar em 1866, e dispôs, atendendo às antigas reivindicações da Companhia, que o excesso do rendimento liquido, deduzidos $12 \%$ para os acionistas e $4 \%$ para o fundo de reserva, fosse também acumulado nesse mesmo fundo, ao invés de reverter para a Fazenda Pública. ${ }^{30}$

Não obstante, chegado o ano de 1866, o governo informou à Companhia Brasileira de que, em conformidade com o que fora disposto no contrato aprovado pelo Decreto de 17 de dezembro de 1859 , este mesmo contrato terminaria no último dia daquele ano. ${ }^{31}$ A Companhia, desejosa de manter seus privilégios contratuais e, sobretudo, os lucros auferidos com o afretamento de alguns de seus vapores pelo Governo, envolvido na Guerra do Paraguai, ${ }^{32}$ argüiu que as exigências do contrato de 1863 , como a renovação de sua frota pela aquisição de novos paquetes, eram muito onerosas: ou o Governo aceitava aquela prorrogação do prazo até 1872 , ou ela seria obrigada a encerrar suas atividades.

De fato, a Companhia manifestara sua intenção de cessar com o serviço no final de 1866 , ponderando que, se com a antiga subvenção, quando a moeda não estava depreciada e não sofria a concorrência de outras linhas de paquetes a vapor, não havia podido cumprir com as suas obrigações contratuais, se não às custas do sacrifício de grande parte de seu capital; "certamente cavaria a própria ruína, continuando com o serviço". ${ }^{3}$ Mas, alegando seu desejo de remover qualquer dificuldade que a interrupção do serviço pudesse suscitar à administração pública, propôs-se a continuar por alguns meses, mediante novas condições. Como, naquele momento, "não sendo possível suspender este serviço de incontestada importância para o comércio e para a adminis-

Brasil, CD, Burlamarque, Sessão de 27/06/1865, pp. 180-181, Rio de Janeiro: Typographia Villeneuve, 1865 .

"A Companhia Brasileira de Paquetes a Vapor e seus detratores. Rio de Janeiro:Typographia Americana, 1869 , p. 7.

Apenas no ano de 1866, o Governo fretou seis dos oito vapores da Companhia. Um deles, o paquete "Falcão", naufragou durante uma batalha, provocando revolta nos acionistas da Companhia e uma reclamação oficial da sua diretoria. Relatório da Cia. Brasileira de 1867, Rio de Janeiro: M. Barreto, 1868.

${ }_{33}$ Brasil, Ministério da Agricultura, Comércio e Obras Públicas, Relatório (doravante RMA), Manoel Pinto de Souza Dantas, 1867, p. 148, Rio de Janeiro: Typographia do Diário do Rio de Janeiro, 1868. 
tração pública", o Governo aceitou o oferecimento, em caráter provisório, podendo qualquer das partes contratantes exonerar-se de suas obrigações com aviso prévio de sessenta dias. Em contrapartida, obrigava-se a Companhia a transportar gratuitamente, e sob sua responsabilidade, qualquer soma que o Tesouro Nacional e as Tesourarias Provinciais tivessem de remeter de um para outro ponto de escala de seus navios. ${ }^{34}$

Subsistia este acordo, quando a baixa sensível do câmbio sobre Londres provocou uma forte desvalorização do mil-réis. O aumento dos preços dos artigos importados degradou de tal maneira a receita da Companhia, cujo estado, até então, era considerado "muito satisfatório", que a induziu a solicitar a garantia do Governo Imperial pelo acréscimo do custo, ao menos, do carvão, correndo por sua conta o aumento da despesa proveniente de outros artigos de importação. Realmente, o estado de guerra e a conseqüente necessidade de transportar do Norte para o Sul, e para a frente de batalha, soldados, armas, munições e curativos, favoreciam as pretensões da Companhia, e, segundo o deputado Leitão da Cunha, a idéia de substituí-la por uma empresa estrangeira tornara-se, naquelas circunstâncias, descabida:

"Penso que o Honrado Ministro deve-nos tirar deste estado inteiramente inconveniente. O governo não pode prescindir desta linha de vapores, e comojá disse, me parece escusado mostrar que a preferência de uma companhia brasileira à americana é de simples intuição." ${ }^{35}$

A guerra contra o Paraguai, sem dúvida nenhuma, viera favorecer não só o estado financeiro da Companhia, "que auferiu grandes lucros com as passagens das praças de pré" (militares sem patente de oficial), como também melhorar sua relação com o Governo Imperial, especialmente quando este se viu na contingência de pagar fretes "fabulosos", de 22:000\$000 réis por mês às empresas estrangeiras que afluíram ao nosso mercado desde que "se soube na Europa que o governo imperial precisava de transporte para o Rio da Prata". ${ }^{36}$ Foi então que o ministro da Guerra, o barão de Uruguaiana, convenceu a direção da Companhia Brasileira a que comprasse vapores a fim de fretá-los para o Governo. E

\footnotetext{
${ }^{34}$ Idem, p. 149.

${ }^{35}$ Leitão da Cunha, $C D$, Sessão de 30/06/1868,p. 435.

${ }^{36}$ Idem, p. 434.
} 
os fretou a 18:000\$000 réis mensais. Além disso, outro fato aproximou a Companhia do Governo: durante a guerra, ao invés de fazer o abatimento a que estava obrigada, de $5 \%$ nos fretes do governo, espontaneamente, ela fizera a redução de $20 \%$, prestando-lhe um grande serviço. ${ }^{37}$

Aproveitando-se desta conjuntura favorável, os defensores dos interesses da Companhia Brasileira procuraram, com êxito, dissuadir o Ministro da Agricultura a firmar um contraio permanente com ela ou, por qualquer outro modo, sair daquele estado provisório em que "há doze anos está suspensa entre o céu e a terra", ${ }^{38}$ uma vez que, por não estar em vigor nenhum contrato perfeito (mas um contrato provisório quejá durava três anos), não lhe era permitido, por um lado, pretender uma liquidação vantajosa, e, por outro, ela não podia "reformar seu material flutuante, que se acha quase todo estragado e impróprio para o serviço". ${ }^{39}$ Finalmente, suas pretensões receberam um parecer favorável e a reforma de seus estatutos foi aprovada pelo decreto $\mathrm{n}^{\circ}$. 4178 de $1867 .{ }^{40}$

No entanto, a oposição continuava a criticar e denunciar o contrato da companhia com o governo alegando que nos seus vapores "o tratamento é péssimo, não há acomodações, admitem maior número de passagens que a lotação, é uma perfeita miséria", ${ }^{41}$ e que "ela podia prescindir da subvenção em compensação dos grandes lucros que tem tirado, tanto que está dando dividendo de $20 \% " .{ }^{42}$ E tanto fizeram que, no ano seguinte, o novo ministro da Agricultura, Antão Fernandes Leão, assumia uma posição radicalmente oposta, discordando do seu antecessor, e, em seu relatório, afirmava:

"O serviço que a companhia atualmente presta não está em rela-

Ibidem.

${ }^{38}$ Gama Abreu, $C D$, Sessão de 06/07/1868,p. 13.

Leitão da Cunha, CD, Sessão de 30/06/1868,p. 434.

${ }^{40}$ Ibidem.

Corrêa das Neves, CD, Sessão de 06/07/1868,p. 64.

"Pelo que respeita ao tratamento, procede ele em parte dos nossos hábitos, e a eles se devem também atribuir outros defeitos que se notam no serviço. Cumpre porém [não] desconhecer que a mesa é mais farta, e muito mais generosa e liberal que a dos ingleses, posto que lhe falte essa solenidade, esse luxo que se nota nesta." Gonçalves Martins (Ministro do Império), Senado, Sessão de 13/08/1852, p. 366.

${ }^{42}$ Cândido Torres Filho, CD, Sessão de 08/07/1868, p. 94. 
ção com o auxílio que recebe dos cofres públicos. Seus vapores, pela maior parte, velhos é estragados, são morosos e pouco cômodos."43

Se ele mesmojustificava, mas apenas em parte, a falta de investimentos na aquisição de novos vapores pela incerteza em que estava a diretoria de ver o seu contrato renovado; era para, logo em seguida, acrescentar:

"Todavia, no estado de prosperidade a que chegou quase às expensas do Tesouro, não lhe será oneroso proporcionar ao governo e ao público um serviço mais rápido e regular, correspondendo assim às repetidas provas de benevolência que tem recebido do governo." ${ }^{4+4}$

Enfim, durante a discussão do orçamento de sua pasta, ele justificava a não-renovação do contrato de navegação com a Companhia Brasileira (apesar de admitir "que este serviço devia ser de preferência confiado a uma companhia brasileira"45) alegando as dificuldades provocadas pela guerra: a diferença de câmbio, os problemas financeiros, a carestia de todos os gêneros e a elevação do preço do combustível eram tão grandes que, se o governo tivesse de "renovar por longos anos um contrato desta ordem" com a companhia, estes preços elevados teriam de servir de base para os cálculos,

"[e] o governo não consultaria os interesses públicos fazendo um contrato quando tudo nos faz crer as coisas melhorarão com o término da guerra, que não pode prolongar-se por muito tempo." ${ }^{46}$

Ele concluía lembrando que o Governo estava habilitado, com a autorização do corpo legislativo, incluída na lei do orçamento, a abrir a concorrência para renovar o serviço daquela navegação, preferindo em igualdade de condições a Companhia Brasileira. E estas condições eram: redução de despesa e melhoramento do serviço.

Antão Fernandes Leão, RMA, 1868, p. 109.

${ }^{44}$ Ibidem.

${ }^{45}$ Antão Fernandes Leão (Ministro da Agricultura), CD.Sessão de 08/07/1868,p. 93.

${ }_{46}$ Idem, p. 93-94. 
A relação da Companhia Brasileira com o Governo se degradava rapidamente. O novo detentor da pasta da Agricultura, Diogo Velho Cavalcanti de Albuquerque, que assumira o Ministério em janeiro de 1870 , encontrou por decidira questão relativa à arrecadação da quantia de 430:875\$760 réis, que correspondia aos lucros líquidos realizados pela Companhia em 1865 e que, pelo contrato de 1859, pertencia ao Tesouro Nacional. À vista do resultado do exame feito por um empregado do Tesouro, que concluiu que a diretoria da Companhia havia manipulado os balanços de 1863 a 1865 , a fim de anular todo o saldo deste último ano, ela foi intimada a recolher aquela quantia ao Tesouro. Ordem que a diretoria da Companhia declarou não poder cumprir, e a que foi coagida em juízo, sendo ordenada sua execução."

Na verdade, com o fim da Guerra do Paraguai, a aliança,já bastante surrada, entre o Governo e a Companhia Brasileira, a quem esta mesma guerra dera novo alento, chegara a seu termo. Seis anos antes, em 1865, em seu discurso na Câmara dos Deputados a propósito da renovação do seu contrato, o ministro da Agricultura, Antônio Francisco de Paula e Souza,já havia deixado bem claro as razões do fracasso desta união:

"Se uma proteção tão larga e tão vasta, por tanto tempo dispensada, não pôde fazer medrar essa indústria, força é confessar que ela não pode medrar entre nós, é uma indústria que não acha em nosso solo meios de radicar-se, é preciso, pois, que a arranquemos do tesouro e a abandonemos, porque não devemos tirar aos contribuintes gerais somas enormíssimas, cerca de 2.500:000\$000 anualmente, para fazer o movimento de interesses muito pouco superior ao valor dos fundos da Companhia que se reuniu!"ss

Solo, medrar, radicar, arrancar... Pelos termos, parecia que o Ministro falava para uma platéia de agricultores. E talvez fosse: um público de representantes dos fazendeiros que não via mais sentido algum em subvencionar uma empresa que, a seus olhos, fora mal administrada e, na nova conjuntura, deixara de ser imprescindível.

${ }^{47}$ Em 31/10/1871, ela entrou em liquidação vendendo, em leilão público, bens avaliados em 1.206:000\$000 réis por 590:000\$000 réis. Brasil, Fazenda Nacional, Processo s/n de 16/11/1872. Ação movida contra a Companhia de Paquetes a vapor.

${ }^{48}$ Antônio Francisco de Paula e Souza (Ministro da Agricultura, Comércio e Obras Públicas), CD, Sessão de 27/06/1865,p. 186. 
Na verdade, a Companhia Brasileira, que não renovara sua frota de vapores e não se modernizara, vinha sofrendo a concorrência de outras companhias de paquetes a vapor, muito especialmente da norte-americana, a United States and Brazil Mail Steam Ship Co., que ligava mensalmente o Rio de Janeiro a Nova York, numa extensão de 129.600 milhas, passando pelas capitais do Norte, e era subvencionada pelo governo norte-americano com a quantia de 300:000\$000 réis, e pelo brasileiro com uma de 200:000\$000 réis. Apesar desta subvenção corresponder à metade da que a Companhia Brasileira recebia, ${ }^{49}$ a empre sa norte-americana, segundo o deputado Tavares Bastos, oferecia um serviço melhor. ${ }^{50}$

Aberta pelo Governo, a concorrência para a linha do Litoral Norte brasileiro, a companhia norte-americana se apresentou e ganhou. ${ }^{51}$ Em seu último relatório, de 31 de março de 1871, a direção da Companhia Brasileira de Paquetes a Vapor comunicava laconicamente a seus sócios:

"Concorremos ao concurso apresentando nossa proposta para a linha costeira a qual ficou preterida por outra de condições mais favoráveis aos cofres públicos."

Terminava, assim, quiçá a primeira tentativa da burguesia brasileira de encontrar uma forma de acumulação de capitais, em grande escala, dentro dos novos padrões da economia mundial capitalista - ou seja, através da criação de uma empresa com a formajurídica de sociedade anônima, muito antes mesmo que a lei sobre as sociedades de capital fosse sancionada, em 1849, e o Código Comercial de 1850 regulasse sua existência.

49 Como se pode perceber da análise de seus Relatórios, em 1857, esta subvenção anual mais as passagens e fretes pagos pelo governo correspondiam a $82 \%$ de sua receita. No período de 1862 a 1865 , esta subvenção montava a 1.056 contos de réis, e continuava sendo muito elevada em relação ao capital social da empresa de 2.500 contos. Os seus lucros continuavam a advir primordialmente das subvenções do Estado, e só secundariamente de suas atividades propriamente comerciais.

50 A. C.Tavares Bastos, O Vale do Amazonas, 3a. ed.,São Paulo: Editora Nacional, 1975, pp. $112-113$.

A linha do Sul foi contratada com a Companhia Liverpool Brazil and River Plate Steam Navigation. Barão de Itaúna, RMA, 1871. 
Nascida da união com o Estado imperial, e sob sua tutela, a Companhia Brasileira de Paquetes a Vapor teve que se sujeitar ao seu projeto político. Se, de início, este projeto a favoreceu, muito logo ficou evidente que a sujeição às razões do listado (manifestada sob a forma da subvenção e do monopólio que a protegiam de toda concorrência) desestimulara o espírito empresarial, empreendedor e criativo, que devia norteá-la, paralisando-a. Estruturalmente dependente não suportou o seu divórcio do Estado, quando este a trocou pela empresa estrangeira, e morreu.

"Mas isto prova bem que no começo das empresas novas no País é uma necessidade fazer-se algum sacrifício, para depois se chegar ao ponto de dizer-se: pode-se hoje dispensar." ${ }^{52}$

Francisco Gonçalves Martins (Ministro do Império), Senado, Sessão de 27/05/1852, p. 248 . 